\title{
Correspondence
}

To the Editor of the Journal,

\section{THE SOUTHERN ROUTE}

Michael Richey, in his article entitled Jester's Transatlantic Voyage (this Journal, 22, 127), says that as far as he knows no small yacht before him sailed from Europe to America along the southern trade wind route. But while his own voyage is unique in its own way I would like to bring to his notice the crossing of another single-hander who sailed his boat from Helford to New York along the trade wind route in 1948-9 and wrote a compelling book about it called Single Handed Passage. Edward Allcard sailed Temptress (a 34 -ft. yawl) to New York via Gibraltar (where he had to carpenter a new mast), taking 80 days to sail from there to New York. He sailed as far south as $22^{\circ} \mathrm{N}$. 'before swinging northwestwards between the West Indies and Bermuda and thence to New York, thus getting three benefits: the trade winds, the north equatorial current and the Gulf Stream off the American coast. This distance involves sailing not far short of five thousand miles.' I would like to add for interest that he had no selfsteering gear, taking normally a ten-hour trick at the helm and lashing the helm while below decks. Unlike Slocum in the Pacific, he found that the trade winds left him no time to read or mend his socks.

47 Blackheath Park,

David McLean

London, $\mathrm{SE}_{3}$.

\section{Michael Richey writes:}

I am grateful to Mr. McLean for the correction: Gibraltar is of course Europe. But from a point so far south there is really no sensible alternative to the southern route. And the same argument applies to a number of other voyages either via the Canaries or Gibraltar or to the West Indies. I should really have said from the Channel to the United States because from there the southern route is almost two-thirds as long again as the direct, and this is what fascinated me, because the route seems to have held its own in the days of commercial sail.

It must, incidentally, be seldom that a steamship takes this route in preference to a more direct one but an old friend, Commandant Jacques Traizet, late of the Compagnie Générale Transatlantique, commenting on my article as it appeared in France (Navigation, Paris, No. 65) writes:

Comme vous avez eu raison de choisir la route Sud. Je me souviens qu'en Décembre 1935, j'ai suivi sensiblement la même route avec le Saint Lo un liberty ship à lège, et ai mis 20 jours pour aller de Bordeaux à Baltimore. (ll y avait de fortes dépressions sur l'Atlantique Nord).

Par contre un de mes camarades, sur un autre liberty, parti le même jour du Havre a mis quatre jours de plus, en passant un peu au Nord des Açores. 